University of Nebraska - Lincoln

DigitalCommons@University of Nebraska - Lincoln

Publications, Agencies and Staff of the U.S.

Department of Commerce

U.S. Department of Commerce

2011

Recreational fishing depredation and associated behaviors involving common bottlenose dolphins (Tursiops truncatus) in Sarasota Bay, Florida

Jessica R. Powell

University of South Florida, jessica.powell@noaa.gov

Randall S. Wells

Mote Marine Laboratory

Follow this and additional works at: https://digitalcommons.unl.edu/usdeptcommercepub

Part of the Environmental Sciences Commons

Powell, Jessica R. and Wells, Randall S., "Recreational fishing depredation and associated behaviors involving common bottlenose dolphins (Tursiops truncatus) in Sarasota Bay, Florida" (2011). Publications, Agencies and Staff of the U.S. Department of Commerce. 308.

https://digitalcommons.unl.edu/usdeptcommercepub/308

This Article is brought to you for free and open access by the U.S. Department of Commerce at DigitalCommons@University of Nebraska - Lincoln. It has been accepted for inclusion in Publications, Agencies and Staff of the U.S. Department of Commerce by an authorized administrator of DigitalCommons@University of Nebraska - Lincoln. 
MARINE MAMMAL SCIENCE, 27(1): 111-129 (January 2011)

(C) 2010 by the Society for Marine Mammalogy

DOI: $10.1111 / \mathrm{j} .1748-7692.2010 .00401 . x$

\title{
Recreational fishing depredation and associated behaviors involving common bottlenose dolphins (Tursiops truncatus) in Sarasota Bay, Florida
}

\author{
Jessica R. POWELL ${ }^{1}$ \\ University of South Florida, \\ College of Marine Science, \\ 1407 th Avenue South, \\ St. Petersburg, Florida 33701, U.S.A. \\ and \\ Chicago Zoological Society, \\ c/o Mote Marine Laboratory, \\ 1600 Ken Thompson Parkway, \\ Sarasota, Florida 34236, U.S.A. \\ E-mail: jessica.powell@noaa.gov

\section{RANDALL S. WeLLS} \\ Chicago Zoological Society, \\ $\%$ Mote Marine Laboratory, \\ 1600 Ken Thompson Parkway, \\ Sarasota, Florida 34236, U.S.A.
}

\begin{abstract}
Odontocete depredation involves stealing or damaging bait or prey already captured by fishing gear. The increase in depredation is of concern for small stocks of cetaceans because interactions with fishing gear can lead to serious injury or mortality through entanglement or ingestion. Using long-term data sets available for the bottlenose dolphin (Tursiops truncatus) community in Sarasota Bay, Florida, we investigated recreational fishing gear interactions by (1) examining temporal patterns in depredation and associated behaviors from 2000 to 2007; (2) quantifying the behavior of dolphins that depredate or engage in associated behaviors; and (3) identifying factors associated with the rise in depredation locally. The number of incidents of dolphins (primarily adult males) interacting with recreational anglers and boaters increased following 2004. Depredation and associated behaviors increased during red tide lags and tourist seasons during times of prey depletion and heightened angler and boater activity. Dolphins with a history of fishing gear interactions shifted away from natural activity patterns and were more likely to be within $50 \mathrm{~m}$ of fishing lines. Recreational fishing gear interactions were attributed to a two percent population decline in Sarasota Bay in 2006 and need to
\end{abstract}

\footnotetext{
${ }^{1}$ Current address: NOAA Fisheries Service, Southeast Regional Office, 233 13th Avenue South, St. Petersburg, Florida 33701, U.S.A.
} 
be considered along with other cumulative human impacts in the development of conservation measures for dolphins.

Key words: depredation, behavior, recreational fishing, human interactions, common bottlenose dolphin, Tursiops truncatus, foraging, red tide, Karenia brevis.

Depredation is the act of a predator stealing or damaging bait or prey item already captured by some other process (Zollett and Read 2006). Depredation of commercial and recreational fishing gear by cetaceans is a growing problem around the world (Broadhurst 1998, Secchi and Vaske 1998, Donoghue et al. 2002, Noke and Odell 2002, Cox et al. 2003, Lauriano et al. 2004, Brotons et al. 2008, Sigler et al. 2008). Longline fishery depredation by larger odontocetes has recently been recognized as increasing in frequency, geographic extent, and severity (Read 2008). Removal of, or damage to, bait or catch by cetaceans creates an economic loss, degrades a recreational experience, and increases the chance of retaliation by the angler (Read 2008). In addition, any activities that bring dolphins into contact with fishing gear have the potential to seriously injure or kill the animals through entanglement or ingestion (Wells and Scott 1994; Gorzelany 1998; Wells et al. 1998, 2008).

In the state of Florida, specifically the west coast, there has been a recent increase in common bottlenose dolphin (Tursiops truncatus) entanglement and ingestion of recreational fishing gear (NOAA 2006). In 2006, five stranded dolphins (four adults and one calf) were recovered in Sarasota Bay that were either entangled in or had ingested recreational fishing gear. The four adults recovered with fishing gear were all long-term residents of the Sarasota Bay dolphin community that have been studied since 1970 (Wells 1991, 2003) and only one had a previous history of angler interactions. The fishing gear interaction for three of the adults was determined as the cause of death. The fishing-gear-related deaths in 2006 resulted in a loss of more than $2 \%$ of the 160 resident Sarasota dolphins, an unprecedented mortality level that would likely be unsustainable for this dolphin community. Two rescues of Sarasota Bay dolphins entangled in fishing gear occurred in 2007.

As human populations continue to increase in Florida coastal areas, dolphins are increasingly exposed to the anthropogenic effects of recreational fishing and boating. Within Sarasota and Manatee counties, the home range of the Sarasota Bay resident dolphins, the total number of registered boats has quadrupled since 1970 to 45,348 boats in $2007 .^{2}$ Marine recreational fishing in the United States increased by $20 \%$ from 1996 to 2000 (Sutinen and Johnston 2003), with the state of Florida having the greatest number of saltwater recreational anglers (U.S. Dept. of the Interior et al. 2006). Increasing numbers of anglers, many more of whom are releasing incapacitated, injured, or undersized catch through "catch and release" practices (Van Voorhees and Pritchard 2008), provide greater opportunities for dolphins to associate boats and fishing piers with easy prey in the forms of released catch, bait, or caught fish on line. This potential problem is also reinforced and exacerbated through direct, illegal feeding of dolphins, as has been documented in the Sarasota area (NOAA 1994, Cunningham-Smith et al. 2006).

For management purposes, it is important to understand the nature of depredation and its associated behaviors of patrolling, scavenging, begging, and provisioning

\footnotetext{
${ }^{2}$ Personal communication from Boyd Walden, Chief, Bureau of Titles and Registrations, Division of Motor Vehicles, 2900 Apalachee Parkway, MS68, Tallahassee, FL 32399, January 2007, July 2009.
} 
Table 1. Working definitions of depredation and associated behaviors created to quantify human interaction (HI) behaviors when interacting with boaters, anglers, fishing vessels, or fishing piers.

\begin{tabular}{lc}
\hline \hline Activity & Definition \\
\hline Patrol & Dolphin is traveling in repeated directions along fishing \\
lines, fishing boats or pier structure or when a dolphin \\
continues to mill after multiple surfacings near fishing \\
boats, fishing lines, or pier. Dolphin must be within at \\
least 20 m of boats, lines or pier. \\
Dolphin is behaving in way to elicit food from a person, \\
such as bringing head out of the water and/or opening \\
mouth at surface. \\
Dolphin is observed feeding on an angler's bait or catch that \\
was thrown back into the water (not on an angler's line). \\
The intent of the angler was not to feed the dolphin, but \\
rather to throw back unwanted bait or catch. \\
Dolphin successfully takes and feeds on all or part of the \\
bait or catch from an angler's line. \\
Dolphin attempts to take bait or catch off an angler's line \\
but is unsuccessful or aborts the behavior before taking \\
bait or catch (e.g., dolphin chases line with catch but line \\
is removed from the water before dolphin takes catch). \\
This category is also used when it is not possible to \\
determine the success of the depredation attempt. \\
Dolphin is intentionally being fed bait, catch, or other \\
items by individual(s). Person(s) may be directly \\
dropping item in dolphin's mouth or throwing item at \\
dolphin.
\end{tabular}

(Table 1). It is necessary to identify contributing factors (anthropogenic, behavioral, and environmental) that may illicit these behaviors; the frequency and the proportion of the population that engage in these behaviors; and whether or not these frequencies vary with time and specific conditions. Examining possible changes to ranging patterns, habitat selection, and natural activity patterns as well as documenting trends over sex and age classes are also fundamental for quantifying the effects of depredation and associated behaviors (Chilvers and Corkeron 2001, Reeves et al. 2001, Finn et al. 2008).

Changes in activity budgets as a result of depredation and associated behaviors can be useful for assessing impacts on cetacean populations (Lusseau 2003, 2004, 2006; Constantine et al. 2004; Danil et al. 2005; Bejder et al. 2006; Williams et al. 2006). Activity shifts (e.g., reduction in natural foraging or traveling to increase time spent depredating) could have far-reaching effects on dolphins' social structure, habitat selection, or home range size (Chilvers and Corkeron 2001, Lusseau 2003, Danil et al. 2005, Bejder et al. 2006). Results of previous behavioral studies of human and recreational and commercial fishery interactions (e.g., Chilvers and Corkeron 2001, Cunningham-Smith et al. 2006, Finn et al. 2008) suggest that dolphins interacting with humans or fishing gear may select habitat with a concentration of boaters or anglers (e.g., near fishing piers, passes, or channels) and have smaller home ranges because dolphin movements depend largely on the location of prey species (Shane et al. 1986, Ballance 1992). 
Depredation and associated behaviors may spread quickly through a population via cultural transmission (Donoghue et al. 2002, Wells 2003, Whitehead et al. 2004, Cunningham-Smith et al. 2006). Behavioral plasticity of dolphin foraging has been established in Sarasota Bay and is exemplified in the numerous, documented foraging strategies (Nowacek 2002), suggesting cultural transmission of feeding behaviors (Wells 2003). Relationships between environmental factors and frequency of depredation and associated behaviors may also play a role. Red tide, a harmful algal bloom (HAB) common in the Gulf of Mexico, is caused by a toxic dinoflagellate, Karenia brevis. $K$. brevis produces a suite of brevetoxins (neurotoxins), which kill many organisms through inhalation, trophic transfer, or both (Tester et al. 2000, Flewelling et al. 2005, Fire et al. 2008). In 2005, a severe bloom in Sarasota Bay and surrounding areas depleted typical dolphin prey species and was associated with dolphin behavior changes, such as increased group size, shifts in habitat use, and increased reports of begging and depredation from fishing gear, as well as declines in dolphin body condition (Gannon et al. 2009; R. Wells, unpublished data).

Depredation is expected to be a persistent and increasing problem as humans and cetaceans compete for the same resources (Read 2008). Depredation will likely increase due to a combination of factors, including the decline of prey populations from overfishing by commercial and recreational fisheries, cultural transmission of the behavior through populations, and continued feeding of wild cetaceans by humans (Myers and Worm 2003, Sutinen and Johnston 2003, Wells 2003, Coleman et al. 2004, Whitehead et al. 2004, Read 2008). The use of long-term data sets, like those available for the Sarasota Bay dolphin community, offers a unique opportunity to evaluate dolphin depredation and its associated behaviors. The goals of this study were to (1) examine temporal patterns in depredation and associated behaviors; (2) quantify the behavior of dolphins engaging in depredation and associated behaviors; and (3) identify possible factors that may be associated with the rise in depredation locally.

\section{MATERIALS AND METHODS}

\section{Study Area and Population}

This study was conducted within an approximately $125 \mathrm{~km}^{2}$ area including Sarasota Bay and surrounding waters (i.e., southern Tampa Bay, Palma Sola Bay, Anna Maria Sound, Venice Inlet, and coastal waters) (Fig. 1). This area is home to a community of about 160 resident bottlenose dolphins that has been closely monitored by the Chicago Zoological Society's Sarasota Dolphin Research Program, hereafter referred to as SDRP, since 1970 (Wells 1991, 2003). This community of dolphins was appropriate for study because of the incidence of dolphin-human interactions and the wealth of data that already exists on family lineages, stranding records, age, sex, behavioral history, distribution, and social associations (Wells 1991, 2003).

\section{Behaviors of Interest}

In order to quantify human interactions consistently, activity categories for the natural behaviors of mill, forage, travel, rest, and social interactions (SDRP 2006) were supplemented with working definitions for additional human-interaction (HI) behaviors, which are listed in Table 1. 


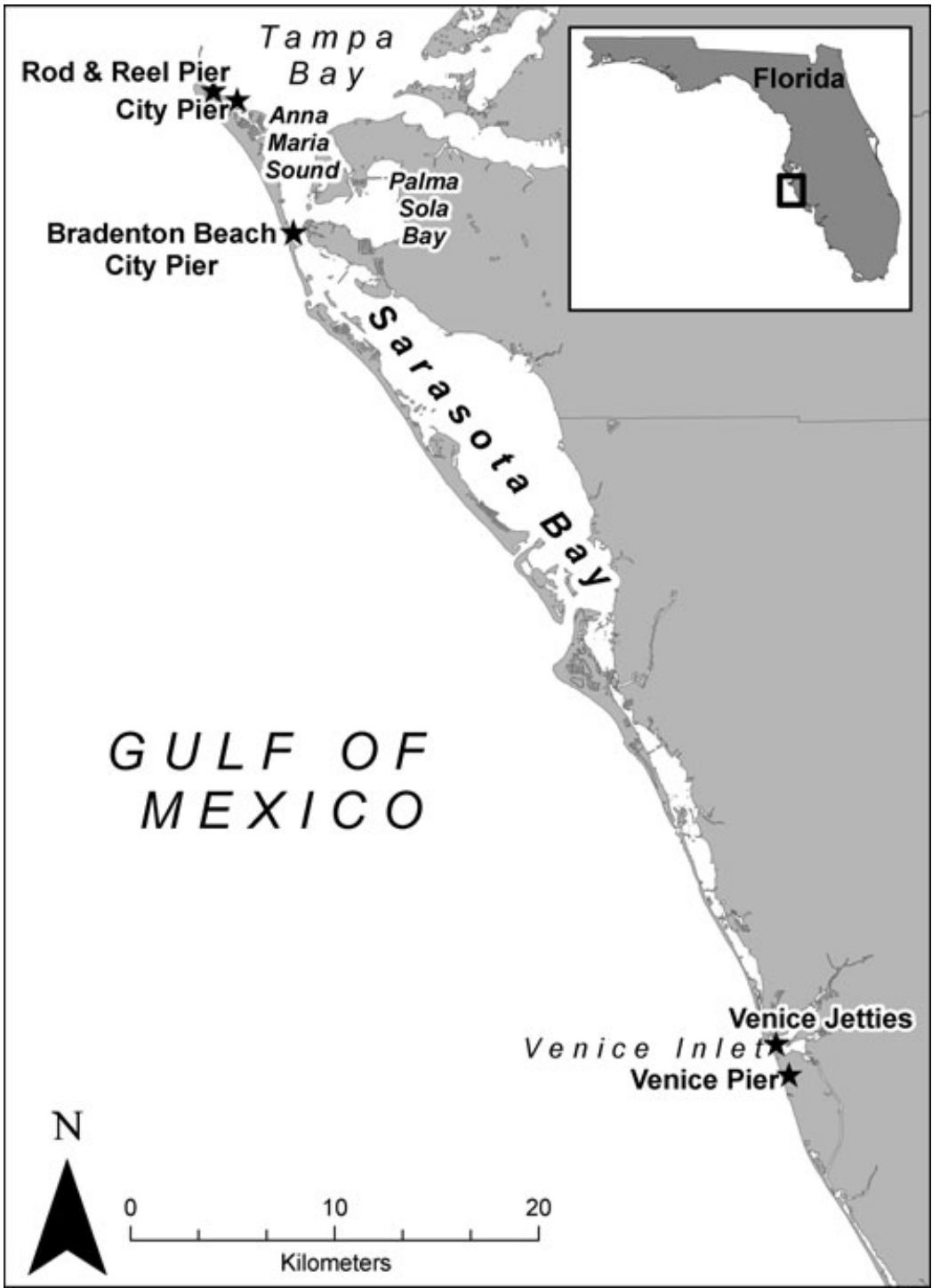

Figure 1. Area surveyed routinely for Sarasota Bay dolphin community residents. Sarasota Bay and surrounding waters are located on the central west coast of Florida. Piers/jetties monitored are marked with stars.

\section{Pier Observations}

Four fishing piers and two jetties were monitored for dolphin presence, fishing effort, and dolphin-HI behaviors. Between May 2007 to July 2007 and October 2007 to April 2008, a total of 64 (378 h) daily surveys were conducted on Anna Maria City Pier, Rod and Reel Pier, Bradenton Beach City Pier, Venice Pier, and the north and south Venice jetties (Fig. 1). Yearly sustained effort on piers or jetties was based 
on the ease and quality of data collection, number of dolphin residents sighted, and apparent or possible dolphin-HI behaviors.

A daily survey of each pier/jetty involved constant monitoring for dolphin presence within a 200-m radius during daylight hours. Standard sighting data were collected and photo-identification was completed using a Nikon D100 digital camera with a 70-300 mm lens and standardized techniques (Würsig and Würsig 1977, SDRP 2006). Additionally, every half hour, data were collected on the number of fishing lines in the water, if bait or lure was in use, and presence or absence of dolphins within $100 \mathrm{~m}$ of the pier/jetty.

When an act of provisioning, scavenging, attempted depredation, or line depredation was observed, the following information was collected: (1) the identity of the dolphin; (2) type of HI behavior; (3) approximate size and species of catch/bait taken (if observed prior to event, otherwise listed as unknown); (4) whether fishing gear was lost and type of gear; (5) number of fishing lines within approximately $15 \mathrm{~m}$ of the interacting dolphin; (6) reaction of the angler/boater to the interaction; (7) the dolphin's associates; and (8) the behavior of the dolphin following the event. A single event of HI behavior was defined as a single act or multiple consecutive acts by a single dolphin involving the same angler or boater or set of associated individuals (e.g., three anglers on a boat).

\section{Focal Dolphin Selection and Focal Animal Behavioral Follows}

A total of 16 dolphins were selected for focal animal behavioral follows (hereafter referred to as focal follows) — eight HI dolphins and eight control dolphins. The particular HI focal dolphins were selected because each had two or more recorded cases of either recreational fishing gear entanglement and/or documented HI behavior prior to July 2007. A control dolphin of the same sex and similar age ( $\pm 5 \mathrm{yr}$ ) and home range was then selected as a counterpart for each HI focal dolphin (Table 2). Control focal dolphins had never been observed entangled in gear or engaging in $\mathrm{HI}$ behavior.

Focal follows were conducted from a 6-m-long center-console outboard boat in the summers of 2007 (July-August) and 2008 (May-July). Standardized techniques for focal follows with Sarasota Bay dolphins (SDRP 2006) were built upon those developed by Altmann (1974). Focal dolphins were followed for up to $2 \mathrm{~h}$ per day and instantaneous data were collected every 3 min on: (1) position, (2) associates, (3) group spread, (4) habitat, (5) number of active fishing lines within $50 \mathrm{~m}$, and (6) number of fishing boats within $100 \mathrm{~m}$. Activity was not instantaneous, but recorded as the activity in which the dolphin engaged in for the majority of observations over the 3-min interval. Position was collected with a Garmin GPS 12, and associates within $200 \mathrm{~m}$ were identified using photo-identification (SDRP 2006). Instances of $\mathrm{HI}$ behavior were documented in the same manner as with pier/jetty surveys. In total, $75.95 \mathrm{~h}$ and $66.05 \mathrm{~h}$ of follow time were completed for HI and control focal dolphins, respectively.

\section{Methods of Analyses}

Depredation and associated behaviors: history and demographics - Yearly and monthly dolphin-HI rates (2000-2007) were calculated based on HI behavior that occurred during routine photo-identification surveys in Sarasota Bay. Ten daily surveys were 
Table 2. Control and human-interaction (HI) focal dolphins selected for focal follows in summers of 2007 and 2008. Mother's names with “*” were documented to engage in depredation or associated behaviors. (BEGR's birth year is a minimum based on date of first observation.)

\begin{tabular}{lccclcc}
\hline \hline $\begin{array}{l}\text { Focal } \\
\text { type }\end{array}$ & $\begin{array}{c}\text { Focal } \\
\text { dolphins }\end{array}$ & Sex & $\begin{array}{c}\text { Birth } \\
\text { year }\end{array}$ & Mother & $\begin{array}{c}\text { Summer 2007 } \\
\text { follow time (min) }\end{array}$ & $\begin{array}{c}\text { Summer 2008 } \\
\text { follow time (min) }\end{array}$ \\
\hline HI & BEGR & M & $<1990$ & Unknown & 240 & 600 \\
Control & F110 & M & 1984 & Unknown & 240 & 360 \\
HI & C354 & M & 1992 & FB35 & 240 & 360 \\
Control & C834 & M & 1992 & FB83 & 240 & 360 \\
HI & FB78 & M & 1972 & Unknown & 240 & 360 \\
Control & FB36 & M & 1972 & Unknown & 120 & 246 \\
HI & FB79 & F & 1979 & Unknown & 240 & 360 \\
Control & FB65 & F & 1983 & FB67 & 240 & 360 \\
HI & F106 & M & 1981 & F191 & 240 & X presumed dead) \\
Control & FB10 & M & 1981 & FB63* & 120 & 360 \\
HI & F109 & F & 1995 & FB79* & 240 & 360 \\
Control & F127 & F & 1995 & FB13 & 240 & 240 \\
HI & F222 & M & 1998 & Unknown & 234 & 363 \\
Control & F196 & M & 1998 & F101 & 114 & 363 \\
HI & F232 & M & 2002 & FB75* & 240 & 360 \\
Control & F224 & M & 2002 & FB27 & 240 & \\
\hline
\end{tabular}

conducted each month (weather-permitting) covering the entirety of the survey range twice. To minimize subjectivity, personnel collecting survey data were all trained observers that adhered to specific protocols and behavioral definitions (SDRP 2006). All rates were standardized by effort (number of boat days). Mann-Whitney $U$ tests (StatSoft Statistica 6.1) were used to evaluate whether dolphin-HI were greater during tourist season months (the number of seasonal residents and tourists in the Sarasota area is generally greatest between January and May) $)^{3}$ and whether rates were seasonal (rainy (May-October) or dry (November-April)).

Using all available sighting data, all resident dolphins sighted from 2000 to 2007 were considered in the calculation of the yearly percentage of the total population that engaged in human interactions. Values were also calculated cumulatively in order to determine the percentage of the residential dolphin population that had engaged in human interactions from 2000 through the given year. If an animal died or disappeared, the dolphin was only considered part of the population through the year of its last sighting.

For male, female, immature and mature dolphins entangled or engaging in $\mathrm{HI}$ behavior in 2007, we compared the observed number of known age and sex $(n=$ 33 ) to the expected number using a goodness of fit $G$-test (PopTools: version 3.0, build 5). Animals with a coefficient of association (COA) of $\geq 0.50$ with their mother were considered dependent calves. Females were re-classified as adults based on the birth date of their first calf. Males were considered adults at $13 \mathrm{yr}$, the youngest documented age of paternity (Duffield and Wells 2002).

\footnotetext{
${ }^{3}$ Personal communication from Virginia Haley, President, Sarasota and Her Islands Convention \& Visitor Bureau, 766 Hudson Avenue, Suite A, Sarasota, FL 34236, October 2008.
} 


\section{Depredation and Associated Behaviors related to Red Tide (Karenia brevis) Blooms}

From 2000 to 2007, monthly dolphin-HI rates were compared across K. brevis bloom months, months following blooms (referred to hereafter as lag months), and non-bloom months. A bloom with potential for killing fish was defined when $K$. brevis cell concentrations were $\geq 100,000$ cells/L for three consecutive weeks (S. Fire, ${ }^{4}$ Steidinger et al. 1998). If any day of a month occurred during a bloom, it was counted as a bloom month. A bloom was considered complete on the day when concentrations were $<100,000$ cells $/ \mathrm{L}$ and cell counts remained below this threshold value for three consecutive weeks. The three months following a bloom (or less, if a new bloom occurred) were deemed the lag months in order to account for the time following a bloom when prey stocks are still low and recovering (Fire et al. 2007, Gannon et al. 2009). There were six events that met the criteria as red tide blooms in Sarasota Bay from 2000 to 2007: (1) September-December 2001, (2) July-September 2002, (3) January-October 2003, (4) January-February 2004, (5) January-December 2005, and (6) July-December 2006. Daily K. brevis cell concentrations were provided by Gary Kirkpatrick of the Mote Marine Laboratory Phytoplankton Ecology Program. One-way ANOVAs and Tukey tests were used to compare bloom periods with respect to dolphin-HI rates (SPSS 16.0).

\section{Habitat Selection and Activity Budgets}

For each focal follow, the percentage of time the dolphin spent in each habitat (coastal Gulf waters, open bay, sand, sea grass meadows, mangrove, channel, and pass) or engaging in an activity was calculated and averaged across each dolphin's follow to arrive at values specific to that individual. Attempted depredation, line depredation, and scavenging were not included in the activity budget calculations because these behaviors were always brief events and were never dominant over a 3 min period. Individual means were then averaged across each dolphin category to determine the overall habitat and activity means for control and HI animals.

Habitat and activity means for control and $\mathrm{HI}$ focal dolphins were compared statistically using a custom randomization program built in MATLAB (version 7.4). The one-tailed test uses a test statistic (ratio between control and HI dolphins) determined by randomizing a matrix 10,000 times to estimate the probability of differences in habitat or activity means between $\mathrm{HI}$ and control dolphins.

For further activity analysis, HI (beg, provision, patrol) and natural foraging behaviors were collapsed to determine if control and HI focal dolphins spent similar amounts of time foraging regardless of the strategy involved.

\section{Proximity to Fishing Lines and Boats}

The mean numbers of boats within $100 \mathrm{~m}$ and fishing lines within $50 \mathrm{~m}$ of focal animals were averaged for each animal. The overall means of boats and fishing lines were determined for HI and control dolphins. Means were compared by MannWhitney $U$ tests (StatSoft Statistica 6.1).

\footnotetext{
${ }^{4}$ Personal communication from Spencer Fire, Marine Biotoxins Program, Center for Coastal Environmental Health and Biomolecular Research, NOAA/National Ocean Service, 219 Fort Johnson Road, Charleston, SC 29412, November 2008.
} 


\section{Home Range}

Focal animal home ranges were calculated using sightings from January 2004 to August 2008. When examining the selected data set (2000-2007), the first documentation of a depredation associated behavior, other than provisioning/begging, was in 2004. Therefore, 2004 was considered to be the year depredation associated behaviors were first observed in the population. The Animal Extension Movement Spatial Analyst (version 2.04 beta) in ArcView GIS 3.3 and XToolsPro (version 1.0.1, build 19) in ArcMap (version 9.0) calculated the areas of the $95 \%$ kernel home ranges and $50 \%$ core kernels for each dolphin. The mean sizes of $95 \%$ and $50 \%$ kernels of control and HI dolphins were compared using Student's $t$-test (SPSS).

\section{Pier}

Data from pier surveys were used in a logistic regression (Statistica) to determine the effectiveness, if any, of the following factors serving as predictors for dolphin presence at fishing piers: (1) number of fishing lines with bait, (2) number of fishing lines with lures, and (3) total number of fishing lines. Due to the difficultly in differentiating between bait varieties, specific bait types were not determined. Monthly average differences in dolphin presence, number of baited fishing lines, number of fishing lines with lures, and total number of fishing lines were compared by a one-way ANOVA (SPSS).

\section{Social Behavior: Group Size and Coefficients of Association}

For Sarasota Bay, a group was defined operationally as all dolphins within approximately $100 \mathrm{~m}$ (Wells et al. 1980, 1987). Average group size for each focal dolphin was determined from sightings during 2000-2007. Group size means were calculated for $\mathrm{HI}$ focal dolphins when engaging in depredation or associated behaviors for comparison to their overall mean group size. A Student's $t$-test was performed on these data sets in SPSS.

For each focal dolphin, routine photo-identification sightings from 2004 to May 2008 were used to calculate the half-weight coefficient of association (COA). Only associates with COAs of $\geq 0.10$ were further analyzed to determine if $\mathrm{HI}$ dolphins associated more often with dolphins that also engaged in depredation and associated behaviors than did control dolphins. Student's $t$-test was used for analyses (SPSS).

\section{RESULTS}

\section{Depredation and Associated Behaviors History and Demographics}

The yearly dolphin-HI rate rose in 2002, 2004 and continued to increase in all subsequent years with the greatest increase between 2006 and 2007 (Fig. 2). (The increase from 2001 to 2002 was attributable to an increase in interactions by a single dolphin). Average monthly dolphin-HI rates were significantly greater $(P=0.0421)$ during the tourist season (January-May) from 2000 to 2007 with the greatest number of dolphin-HIs occurring in March (Fig. 3). Interaction rates were not significantly different between rainy and dry seasons $(P=0.0602)$. 


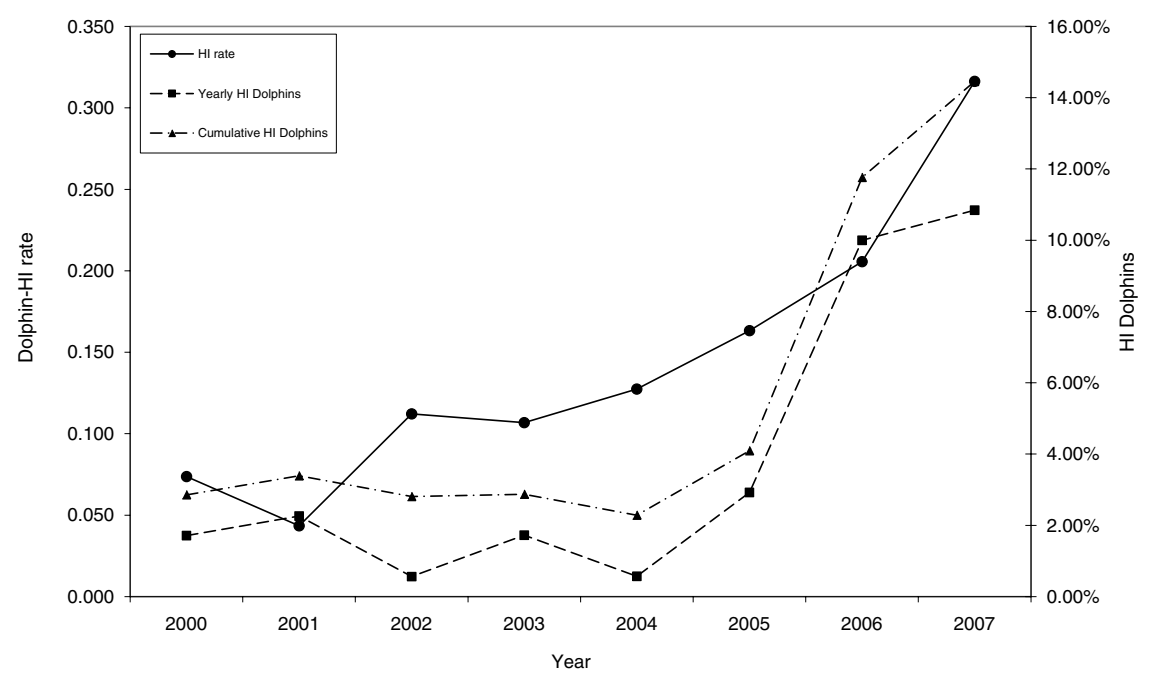

Figure 2. Yearly standardized dolphin-human interaction rates (HI rate), the percent of the dolphin population entangled or engaged in depredation or associated behaviors per year (Yearly HI dolphins), and the percent of the dolphin population seen entangled or engaged in depredation or associated behaviors cumulatively since 2000 (Cumulative HI dolphins).

The number of dolphins entangled or engaged in depredation or associated behaviors has increased each year since 2004 (Fig. 2). Cumulatively, 14\% $(n=24)$ of Sarasota residents have been observed entangled or engaging in depredation or associated behaviors at least once during 2000-2007 (Fig. 2). The observed ratio of immature, mature, males, and females were significantly different from expected

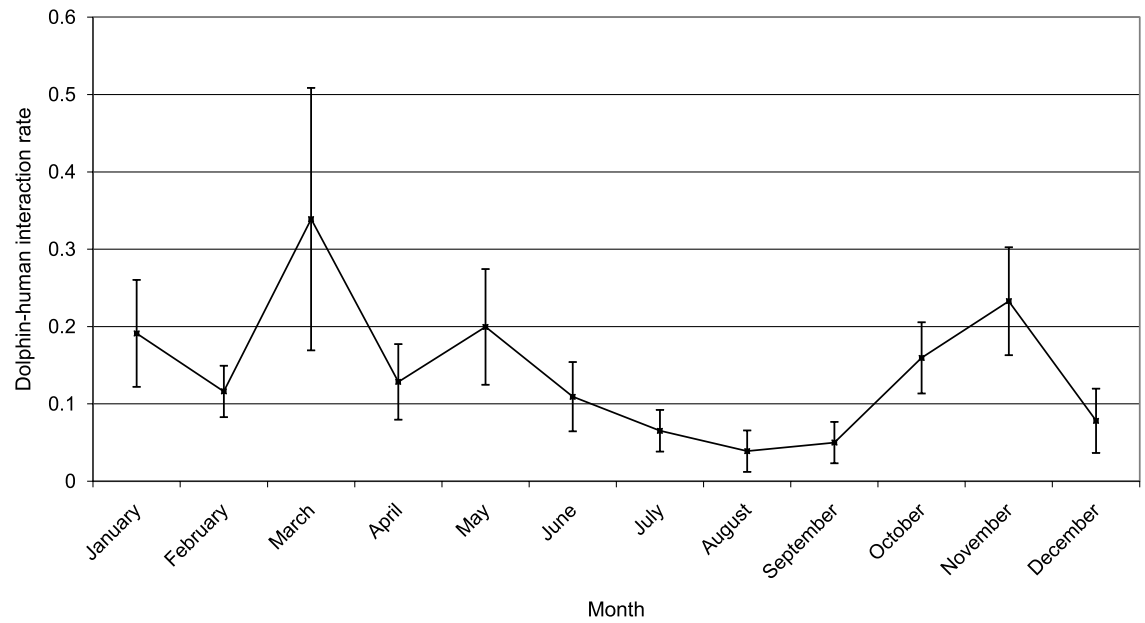

Figure 3. Monthly dolphin-human interaction rates for the Sarasota Bay dolphin community based on routine photo-identification surveys from 2000 to 2007. 
Table 3. Age class and sex distribution of dolphins that were observed entangled or engaged in depredation or associated behaviors in Sarasota Bay (2007).

\begin{tabular}{lrccccccc}
\hline \hline Age class & Total & Males & Females & Unknown & $\%$ Total & $\%$ Male & \% Female & $\%$ Unknown \\
\hline Calves & 1 & 0 & 1 & 0 & 4.17 & 0 & 4.17 & 0 \\
Juveniles & 9 & 5 & 3 & 1 & 37.50 & 20.83 & 12.50 & 4.17 \\
Adults & 13 & 10 & 3 & 0 & 54.17 & 41.67 & 12.50 & 0 \\
Unknown & 1 & 1 & 0 & 0 & 4.17 & 4.17 & 0 & 0 \\
Totals & 24 & 16 & 7 & 1 & & 66.67 & 29.17 & 4.17 \\
\hline
\end{tabular}

values $(P=0.038)$ with adult males being the most over-represented HI age-sex class and adult females being the most under-represented group (Table 3 ).

\section{Depredation and Associated Behaviors in Relation to Red Tide (K. brevis) Blooms}

Dolphin-HI rates were significantly different among $K$. brevis bloom months (0.100 dolphin-human interactions/bloom month), lag months (0.278 dolphinhuman interactions/lag month), and non-bloom periods (0.133 dolphin-human interactions/non-bloom month) $(P=0.006)$. The post-hoc analysis showed that dolphin-HI rates during lag months were significantly greater than those during bloom months $(P=0.043)$ and non-bloom months $(P=0.024)$.

\section{Habitat Selection and Activity Budgets}

There was no statistical difference in the amounts of time control and HI focal dolphins spent in different habitats. HI focal dolphins spent more time milling $(P=0.05)$ and less time engaging in activities including foraging $(P=0.05)$ and traveling $(P=0.02)$ than control dolphins (Fig. 4). When $\mathrm{HI}$ and natural foraging strategies were collapsed, no difference was seen between foraging

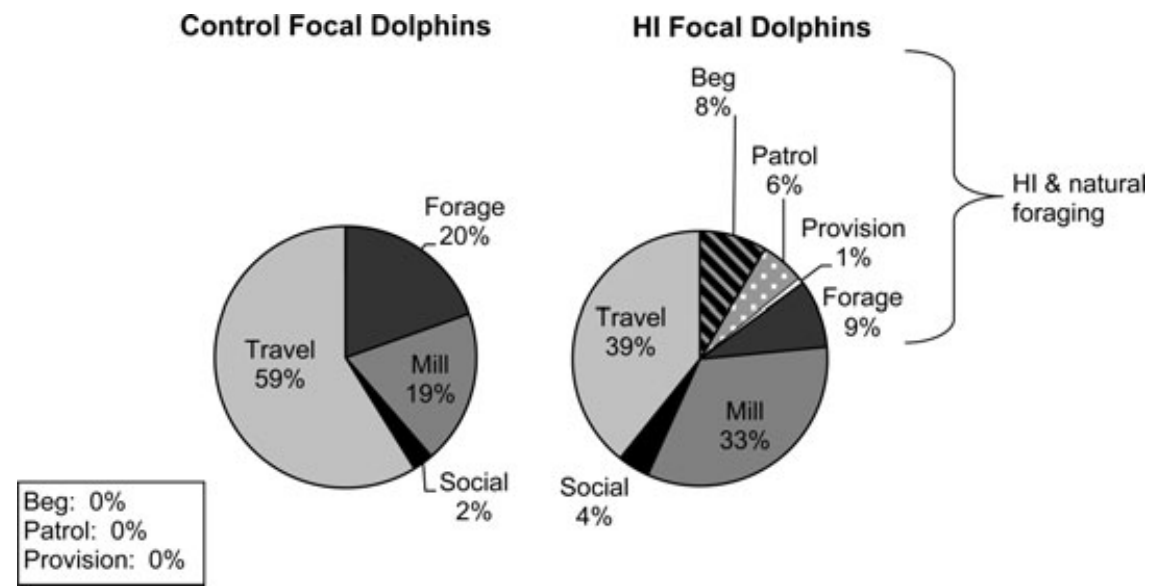

Figure 4. Overall mean activity budgets for control $(n=8)$ and human interaction (HI) $(n=8)$ focal dolphins compiled from summer 2007 and 2008 focal follows. 
$(P=0.4)$, however $\mathrm{HI}$ dolphins still spent marginally more time milling $(P=$ $0.056)$ and less time traveling $(P=0.02)$ (Fig. 4).

\section{Proximity to Fishing Boats and Lines}

There was no significant difference in the likelihood of $\mathrm{HI}$ focal dolphins being within a $100 \mathrm{~m}$ of a greater number of actively fishing boats than were controls (mean $\mathrm{HI}=0.05 \pm 0.01$; mean control $=0.015 \pm 0.04 ; P=0.32$ ). However, HI dolphins were significantly more likely to be within $50 \mathrm{~m}$ of a greater number of fishing lines than control dolphins (mean $\mathrm{HI}=0.10 \pm 0.21$; mean control $=0.01 \pm 0.03 ; P=$ 0.02). When within $50 \mathrm{~m}$ of an active fishing line, control dolphins were never seen to engage in depredation or associated behaviors, whereas HI dolphins engaged in depredation, begging, patrolling, or provisioning approximately $52 \%$ of the time.

\section{Home Range}

No significant differences were found between 95\% kernel home ranges (mean $\mathrm{HI}=94.02 \pm 73.28 \mathrm{~km}^{2}$; mean control $=135.86 \pm 83.15 \mathrm{~km}^{2} ; P=0.3$ ) or $50 \%$ core kernel areas (mean $\mathrm{HI}=14.88 \pm 13.46 \mathrm{~km}^{2}$; mean control $=22.33 \pm$ $15.92 \mathrm{~km}^{2} ; P=0.33$ ) for control or HI focal dolphins.

\section{Pier Observations}

Numbers of fishing lines (with bait, with lures, or total) were not predictors of dolphin presence at fishing piers or jetties, with $r^{2}$ values of $0.001,0.004$, and 0.001 , respectively. Although March 2008 appeared to have the greatest means for total fishing and dolphin presence, no significant differences in dolphin presence $(P=$ 0.513 , Fig. 5), number of baited lines $(P=0.073)$, number of lines with lures $(P=$ $0.262)$, and total number of lines $(P=0.136)$ were detected.

\section{Social Behavior: Group Size and Association Patterns}

The mean group size of $\mathrm{HI}$ focal dolphins (mean $\mathrm{HI}=5.0 \pm 1.2$ ) was less than the mean group size of control focal dolphins (mean control $=6.5 \pm 1.6$ ) and was marginally significant $(P=0.052)$. The mean group size of $\mathrm{HI}$ dolphins when engaging in depredation or associated behaviors was significantly less (mean $\mathrm{HI}=$ $3.0 \pm 1.1$ ) than the overall mean group size of $\mathrm{HI}$ focal dolphins (overall mean $=5.0 \pm$ 1.2) $(P=0.010)$. Neither control nor $\mathrm{HI}$ focal dolphins had significantly greater COAs with dolphins that were involved in depredation or associated behaviors $(P=$ $0.659, P=0.095$, respectively).

\section{DISCUSSION}

Depredation and associated behaviors among Sarasota Bay resident dolphins have risen in recent years as a result of a number of contributing factors, highlighting how quickly a dolphin community can be detrimentally affected by gear ingestion and entanglement risks associated with depredation and associated behaviors. The increase in depredation and associated behaviors may be a consequence of direct 


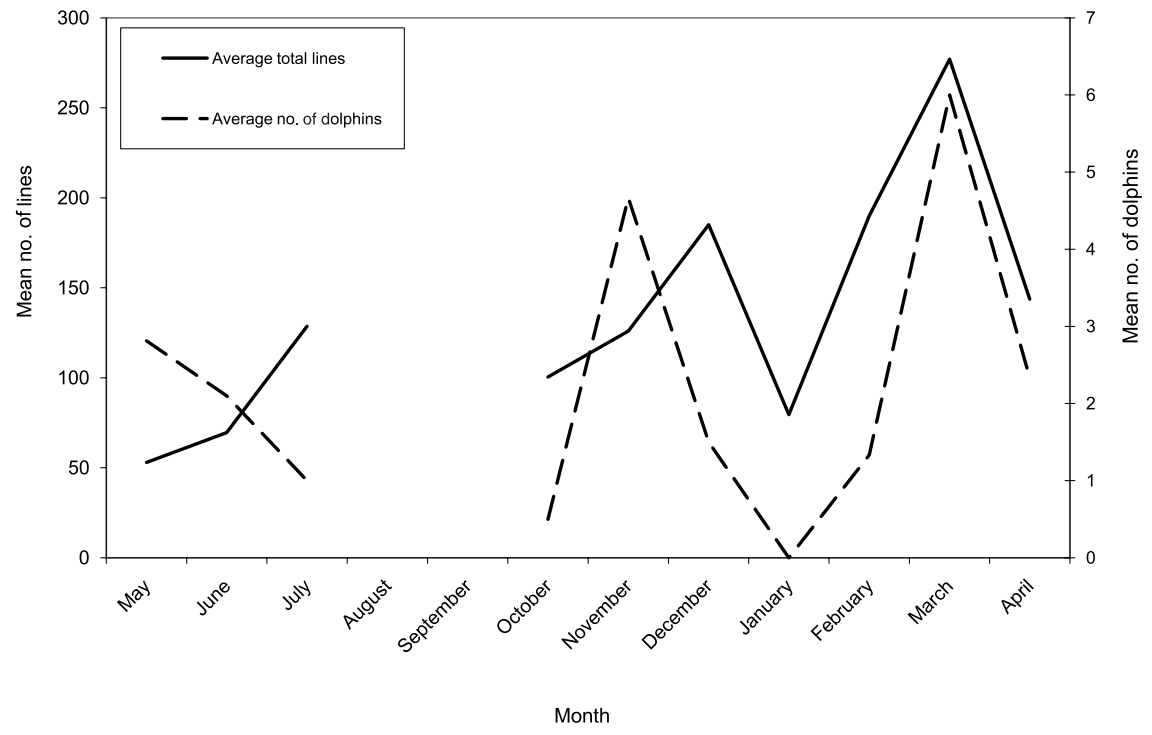

Figure 5. The mean number of dolphins and the mean number of fishing lines (rigged with either bait or lures) by month during pier/jetty surveys from May to July 2007 and October 2007 to April 2008.

competition for resources between anglers and dolphins (Peddemors 2001, Read 2008). The greatest rates of dolphin-human interactions occurred during the tourist season and red tide lags. March, on average, had the greatest rate of dolphinhuman interactions, which also corresponds with the height of the tourist season and presumably increased water traffic in Sarasota County. March is also part of the winter season when dolphins spend more time foraging in passes and coastal Gulf habitats than in sea grass meadows (Wells 1991, 2003). Prey in Gulf waters are not evenly dispersed, making fish potentially more difficult to locate, possibly forcing dolphins to spend more time searching for prey (Wells et al. 1980; Wells 1991, 2003). Although the seasonality of prey distribution may play a role in increased dolphin-human interactions, differences in interaction rates between the two major seasons were not significantly different. However, the combination of less, readily available prey and more anglers or boaters on the water during the tourist season, may cause a greater number of dolphins to turn to anglers and boaters as sources of prey.

The lack of prey and diminished energy stores may explain the increase in depredation following a K. brevis bloom. Dolphins' poor body condition and energy demands from lack of prey may be exacerbated from the toxic effects of brevetoxin (Bossart et al. 1998, Bossart 2006, Fire et al. 2008). Significantly greater rates of dolphinhuman interactions took place during the lag months following a bloom. During lag months, anglers and boaters may begin to return to the water for recreation; however, fish populations are still diminished and may take months to recover (Gannon et al. 2009). Therefore, we suggest that HI rates increase during lag months as dolphins turn to anglers and boaters as supplemental food sources to help sustain them during this period of environmental recovery. 
If depredation and associated behaviors were based exclusively on prey resource availability, then once resources returned to sustainable levels, dolphins would no longer interact with anglers and boaters and would resume natural foraging. However, results showed that dolphin-human interactions have been on the rise since 2004 . Year 2007 was the highest on record for dolphin-human interactions despite the lack of a major red tide bloom-26\% of survey days (approximately $4 \%$ of sightings) reported at least one act of depredation or an associated behavior. Thus, prey depletion may trigger spikes in the behavior, but does not explain the continuation of dolphin depredation and associated behaviors.

Some Sarasota dolphins modified their daily activities to incorporate depredation and associated behaviors. Activities for $\mathrm{HI}$ focal dolphins such as natural foraging and traveling occurred at a lower frequency while milling and depredation associated behaviors occurred at a greater rate. When compared to a previous study in Sarasota Bay by Waples (1995), control dolphins had the same profile for frequency of activity occurrence (traveling, milling, foraging, socializing, and resting) and similar activity values to summer dolphin activity budgets. When the data of Waples (1995) were compared to HI dolphins, the frequency profile of activity occurrence differed and the variation in activity values was much greater. The behavior of $\mathrm{HI}$ dolphins was found to differ not only from control counterparts, but also from a larger study dedicated to understanding natural activity patterns.

Control and HI focal dolphin activity budgets were still marginally to significantly different in traveling and milling activity when HI strategies were collapsed together into a single foraging category. This suggests that depredation associated behaviors, specifically, scavenging, begging, and patrolling, have become part of the foraging behavior repertoire and are not necessarily opportunistic. HI dolphins have rescheduled their natural activity budgets to adjust for human interactions, investing more time into behaviors that are energetically conducive to foraging via human interactions.

Dolphins sometimes cooperatively forage with associates that share similar feeding strategies (Nowacek 1999, Mann and Sargeant 2003), suggesting that associates may serve as vectors for the transfer of depredation and associated behavior (Whitehead et al. 2004). Behavioral transmission of longline depredation has been hypothesized for populations of killer whales (Orcinus orca) and sperm whales (Physeter macrocephalus) (Donoghue et al. 2002). One major avenue for behavioral transmission and social learning that has been well established in bottlenose dolphin communities is between mothers and calves (Nowacek 2002, Wells 2003, Mann and Sargeant 2003). For example, calves in Shark Bay, Australia hunted with techniques exclusive to their mother's foraging repertoire including begging from boats (Mann and Sargeant 2003). Anecdotally, maternal transmission of depredation and associated behaviors has been documented in three separate lineages in Sarasota Bay, including one lineage in which the same associated behavior (patrolling) has been documented in three generations. In addition, Samuels and Bejder (2004) describe the increased risk to human-interacting juvenile dolphins, noting that these animals may not develop suitable foraging skills.

Because adult males were found to engage in human interactions at a disproportionately high rate, this age-sex group may be more likely to incorporate the behavior into their foraging repertoire once learned. Similarly, in Western Australia, males were the more commonly conditioned to human interactions, especially feeding (Finn et al. 2008). Most depredation and associated behaviors appear to be conducive to solitary foragers since these interactions typically involve a single 
prey item struggling on a line, a debilitated thrown-back fish, or the hand-feeding of fish, therefore making this HI foraging strategy ideal for unpaired males (Owen et al. 2002). In fact, all focal adult males seen engaging in depredation or associated behaviors during the course of this study (2007-2008) (BEGR, C354, FB78, F106) were unpaired at the time. Of these, F106 had been paired with FB06 until 2006, when FB06 died from ingesting recreational fishing gear.

However, results from the COA statistical analyses do not support the idea that HI dolphins associate significantly more often with other human interaction animals. Because the nature of depredation and associated foraging lends itself to a solitary strategy, it may be difficult to document transmission or social learning of the behavior. In this study, overall group size was less for HI focal dolphins when compared to controls, and group size was significantly reduced when HI dolphin were engaging in depredation or associated behaviors. Results are consistent with a study in Shark Bay showing that mother-calf pairs (Tursiops sp.) did not form as large or as cohesive of groups inside a designated provisioning area as in non-provisioning areas, and calves had fewer associates in provisioning areas than in non-provisioning areas (Mann and Smuts 1999). A social network study during a dolphin's life stages may be necessary for understanding and pinpointing the transmission of depredation and associated behaviors. Alternatively, individual learning could be facilitated by even infrequent reinforcements from obtaining fish from anglers or boaters.

Initial analyses indicated that $\mathrm{HI}$ dolphins did not spend significantly more or less time in specific habitats or have smaller home ranges and core areas. However, smaller scale habitat selection was supported by the result that HI dolphins were significantly more likely to be within $50 \mathrm{~m}$ of a greater number of active fishing lines, but not more likely to be within $100 \mathrm{~m}$ of a greater number of actively fishing boats; most likely because dolphins are targeting other structures like piers and bridges in addition to boats that support fishing. HI dolphins may be selecting for areas within a close proximity to a greater number of fishing lines in order to provide more opportunities to forage using depredation and associated behaviors. For example, $52 \%$ of the times $\mathrm{HI}$ dolphins were within $50 \mathrm{~m}$ of an active fishing line, the animals were also engaging in depredation or an associated behavior. A similar study in Cockburn Sound, Australia showed the encounter rates for begging dolphins were significantly correlated with the density of recreational boats (Finn et al. 2008). In Moreton Bay, Australia, a coastal community of Indo-Pacific bottlenose dolphins (Tursiops aduncus) known to feed in association with a commercial trawl fishery, selected for deep, offshore habitat conducive to trawling rather than shallow, coastal areas and had $50 \%$ smaller ranges when compared to non-trawler-associated dolphins (Chilvers and Corkeron 2001). Further study of small-scale habitat selection is necessary for a complete understanding of the effects of depredation in this population.

Overall, longitudinal data were invaluable in tracking increased depredation, associated behaviors, and its effects over time within the Sarasota dolphin community. The results enhance our understanding of interactions between dolphins, recreational fishing, and humans and identify factors that may influence these behaviors. Prey resource depletion and increased angling and boater activity corresponded with an increase in depredation and associated behaviors, highlighting critical periods when outreach and management regulations would be most effective and valuable for conservation efforts. Managing depredation and associated behaviors by reducing a dolphin's opportunities to interact with unaware anglers or boaters is essential in order to reduce serious injuries and mortalities from entanglement or ingestion of fishing gear as well as to minimize the number of dolphins engaging in HI foraging. 
Therefore, sustaining outreach efforts and saturating the market in order to educate stakeholders about appropriate actions to take in order to avoid interactions with dolphins as well as how to handle situations that involve dolphins interacting with fishing gear are necessary to stop the spread and extent of depredation.

Managers also need to consider the effects of the increase of depredation stemming from fishermen throwing back fish that are out of season or not of legal size. Situations such as these present especially difficult circumstances as in many instances anglers have no choice but to release an undersized or out of season fish to dolphins that are patrolling the boat waiting for such an opportunity. If the angler were to keep the fish in a live well to later release not in the dolphins' presence, the angler risks violating state or federal fishing laws. Communication and collaboration between state and federal fisheries and marine mammal managers and scientists are needed to help resolve such discrepancies and find agreeable solutions that protect both anglers and dolphins.

\section{ACKNOWLEDGEMENTS}

We thank our dedicated interns and volunteers, especially Kim Atwater, Robin Bisel, Kristen Burtch, Mauricio Cantor, Catherine Deveau, Rachel Eubank, Kerry Foltz, Ellie Glasser, Rebeccah Hazelkorn, and Carolyn Kovacs, whose superb efforts made data collection possible. We also thank Dr. David Mann, Dr. Andy Read, and members of the SDRP and Mann labs for their insightful feedback with project design and analysis. We thank Gary Kirkpatrick and the MML Phytoplankton Ecology Lab for providing K. Brevis cell concentration data. We thank Stacey Horstman and Trevor Spradlin for their time and comments. This work was supported by the Disney Wildlife Conservation Fund, Fish Florida, and an assistantship from the University of South Florida, College of Marine Science. This research was conducted under U.S. National Marine Fisheries Service Scientific Research Permit No. 522-1785.

\section{Literature Cited}

Altmann, J. 1974. Observation study of behavior: Sampling methods. Behaviour 49:227-265. Ballance, L. T. 1992. Habitat use patterns and ranges of the bottlenose dolphin in the Gulf of California, Mexico. Marine Mammal Science 8:262-274.

Bejder, L., A. Samuels, H. Whitehead and N. Gales. 2006. Interpreting short-term behavioural responses to disturbance within a longitudinal perspective. Animal Behaviour 72:1149-1158.

Bossart, G. D. 2006. Marine mammals as sentinel species for oceans and human health. Oceanography 19:134-137.

Bossart, G. D., D. G. Baden, R. Y. Ewing, B. Roberts and S. D. Wright. 1998. Brevetoxicosis in manatees (Trichechus manatus latirostris) from the 1996 epizootic: Gross, histologic, and immunohistochemical features. Toxicology Pathology 26:276-282.

Broadhurst, M. K. 1998. Bottlenose dolphins, Tursiops truncatus, removing bycatch from prawn-trawl codends during fishing in New South Wales, Australia. Marine Fisheries Review 60:9-14.

Brotons, J. M., A. M. Grau and L. Rendell. 2008. Estimating the impact of interactions between bottlenose dolphins and artisanal fisheries around the Balearic Islands. Marine Mammal Science 24:112-127.

Chilvers, B. L., and P. J. Corkeron. 2001. Trawling and bottlenose dolphins' social structure. Proceedings of the Royal Society London B: Biological Science 268:1901-1905.

Coleman, F. C., W. F. Figueira, J. S. Ueland and L. B. Crowder. 2004. The impact of United States recreational fisheries on marine fish populations. Science 305:1958-1960. 
Constantine, R., D. H. Brunton and T. Dennis. 2004. Dolphin-watching tour boats change bottlenose dolphin (Tursiops truncatus) behaviour. Biological Conservation 117:299-307.

Cox, T. M., A. J. Read, D. Swanner, K. Urian and D. Waples. 2003. Behavioral responses of bottlenose dolphins, Tursiops truncatus, to gillnets and acoustic alarms. Biological Conservation 115:203-212.

Cunningham-Smith, P., D. E. Colbert, R. S. Wells and T. Speakman. 2006. Evaluation of human interactions with a provisioned wild bottlenose dolphin (Tursiops truncatus) near Sarasota Bay, Florida, and efforts to curtail the interactions. Aquatic Mammals 32:346-356.

Danil, K., D. Maldini and K. Marten. 2005. Patterns of use of Maku'a Beach, O'ahu, Hawai 'i, by spinner dolphins (Stenella longirostris) and potential effects of swimmers on their behavior. Aquatic Mammals 31:403-412.

Donoghue, M., R. R. Reeves and G. Stone. 2002. Report on the workshop on interactions between cetaceans and longline fisheries held in Apia, Samoa. November 2002. New England Aquatic Forum Series Report 03-1. 44 pp.

Duffield, D. A., and R. S. Wells. 2002. The molecular profile of a resident community of bottlenose dolphins, Tursiops truncatus. Pages 3-11 in C. J. Pfeiffer, ed. Molecular and cell biology of marine mammals. Krieger Publishing Company, Melbourne, FL.

Finn, H., R. Donaldson and M. Calver. 2008. Feeding flipper: A case study of a human-dolphin interaction. Pacific Conservation Biology 14:215-225.

Fire, S. E., D. Fauquier, L. J. Flewelling, M. Henry, J. Naar, R. Pierce and R. S. Wells. 2007. Brevetoxin exposure in bottlenose dolphins (Tursiops truncatus) associated with Karenia brevis blooms in Sarasota Bay, Florida. Marine Biology 152:827-834.

Fire, S. E., L. J. Flewelling, J. Naar, M. J. Twiner, M. S. Henry, R. H. Pierce, D. P. Gannon, Z. Wang, L. Davidson and R. S. Wells. 2008. Prevalence of brevetoxins in prey fish of bottlenose dolphins in Sarasota Bay, Florida. Marine Ecology Progress Series 368:283294.

Flewelling, L. J., J. P. Naar, J. P. Abbott, D. G. Baden, N. B. Barros, G. D. Bossart, M. Y. D. Bottein, D. G. Hammond, E. M. Haubold, C. A. Heil, M. S. Henry, H. M. Jacocks, T. A. Leighfield, R. H. Pierce, T. D. Pitchford, S. A. Rommel, P. S. Scott, K.A. Steidinger, E. W. Truby, F. M. Van Dolah and J. H. Landsberg. 2005. Red tides and marine mammal mortalities. Nature 435:755-756.

Gannon, D. P., E. J. Berens, S. A. Camilleri, J. G. Gannon, M. K. Brueggen, A. Barleycorn, V. Palubok, G. J. Kirkpatrick and R. S. Wells. 2009. Effects of Karenia brevis harmful algal blooms on nearshore fish communities in southwest Florida. Marine Ecology Progress Series 378:171-186.

Gorzelany, J. F. 1998. Unusual deaths of two free-ranging Atlantic bottlenose dolphins (Tursiops truncatus) related to ingestion of recreational fishing gear. Marine Mammal Science 14:614-617.

Lauriano, G., C. M. Fortuna, G. Moltedo and G. Notarbartolo di Sciara. 2004. Interactions between common bottlenose dolphins (Tursiops truncatus) and the artisanal fishery in Asinara Island National Park (Sardinia): Assessment of catch damage and economic loss. Journal of Cetacean Research Management 6:165-173.

Lusseau, D. 2003. Effects of tour boats on the behavior of bottlenose dolphins: Using Markov chains to model anthropogenic impacts. Conservation Biology 17:1785-1793.

Lusseau, D. 2004. The hidden cost of tourism: Detecting long-term effects of tourism using behavioral information. Ecology and Society 9(1):2. Available at http://www.ecologyandsociety.org/vol9/iss1/art2.

Lusseau, D. 2006. The short-term behavioral reactions of bottlenose dolphins to interactions with boats in Doubtful Sound, New Zealand. Marine Mammal Science 22:802-818.

Mann, J., and B. Smuts. 1999. Behavioral development in wild bottlenose dolphin newborns (Tursiops sp.). Behaviour 136:529-566.

Mann, J., and B. Sargeant. 2003. Like mother, like calf: The ontogeny of foraging traditions in wild Indian ocean bottlenose dolphins (Tursiops sp.). Pages 236-266 in D. M. Fragaszy 
and S. Perry, eds. The biology of traditions: Models and evidence. Cambridge University Press, Cambridge, UK.

Myers, R. A., and B. Worm. 2003. Rapid worldwide depletion of predatory fish communities. Nature 423:281-284.

NOAA. 1994. Report to Congress on results of feeding wild dolphins: 1989-1994. National Marine Fisheries Service, Office of Protected Resources. Available at http://www.nmfs.noaa.gov/pr/pdfs/education/dolphin_feeding.pdf.

NOAA. 2006. Bottlenose Dolphins-Increase in depredatory (stealing) behavior and deaths associated with recreational fishing gear. NOAA Fisheries Services, Southeast Regional Office. Available at http://sero.nmfs.noaa.gov/pr/mm/dolphins/bdconservation.htm.

Noke, W. D., and D. K. Odell. 2002. Interactions between the Indian River Lagoon blue crab fishery and the bottlenose dolphin, Tursiops truncatus. Marine Mammal Science 18:819-832.

Nowacek, D. P. 1999. Sound use, sequential behavior and ecology of foraging bottlenose dolphins, Tursiops truncatus. Ph.D. thesis. Massachusetts Institute of Technology/Woods Hole Oceanographic Institution. 196 pp.

Nowacek, D. P. 2002. Sequential foraging behaviour of bottlenose dolphins, Tursiops truncatus, in Sarasota Bay, Florida. Behaviour 139:1125-1145.

Owen, E. C. G., R. S. Wells and S. Hofmann. 2002. Ranging and association patterns of paired and unpaired adult male Atlantic bottlenose dolphins, Tursiops truncatus, in Sarasota, Florida, provide no evidence for alternative male strategies. Canadian Journal of Zoology 80:2072-2089.

Peddemors, V. 2001. A review of cetacean interactions with fisheries and management thereof in South Africa. Proceedings of the Paper Sc/53/E17 presented to the IWC Scientific Committee, July 2001, Hammersmith, London, UK. 42 pp.

Read, A. J. 2008. The looming crisis: Interactions between marine mammals and fisheries. Journal of Mammalogy 89:541-548.

Reeves, R. R., A. J. Read and G. Notarbartolo di Sciara, eds. 2001. Report of the workshop of interactions between dolphins and fisheries in the Mediterranean: Evaluation of mitigation alternatives. Istituto Centrale per al Ricerca Applicata al Mare, May 2001, Rome, Italy. Proceedings of the Paper Sc/53/SM3 presented to the IWC Scientific Committee, July 2001, Hammersmith, London, UK. 44 pp.

Samuels, A., and L. Bejder. 2004. Chronic interactions between humans and wild bottlenose dolphins (Tursiops truncatus) near Panama City Beach, Florida. Journal of Cetacean Research and Management 6:69-77.

SDRP. 2006. Manual for field research and laboratory activities. Sarasota Dolphin Research Program. 62 pp. Available at http://www.sarasotadolphin.org.

Secchi, E. R., and T. Vaske, Jr. 1998. Killer whale (Orcinus orca) sightings and depredation on tuna and swordfish longline catches in southern Brazil. Aquatic Mammals 24:117122.

Shane, S. H., R. S. Wells and B. Würsig. 1986. Ecology, behavior, and social organization of the bottlenose dolphin: A review. Marine Mammal Science 2:34-63.

Sigler, M. F., C. R. Lunsford, J. M. Straley and J. B. Liddle. 2008. Sperm whale depredation of sablefish longline gear in the northeast Pacific Ocean. Marine Mammal Science 24:1627 .

Steidinger, K. A., G. A. Vargo, P. A. Tester and C.R. Tomas. 1998. Bloom dynamics and physiology of Gymnodinium breve with emphasis on the Gulf of Mexico. Pages 133-153 in D. A. Anderson, A. D. Cembella and G. M. Hallegraeff, eds. Physiological ecology of harmful algal blooms. Springer-Verlag, Berlin, Germany.

Sutinen, J. G., and R. J. Johnston. 2003. Angling management organizations: Integrating the recreational sector into fishery management. Marine Policy 27:471-487.

Tester, P. A., J. T. Turner and D. Shea. 2000. Vectorial transport of toxins from the dinoflagellate Gymnodinium breve through copepods to fish. Journal of Plankton Research 22:47-61. 
U.S. Department of the Interior, Fish and Wildlife Service, and U.S. Department of Commerce and U.S. Census Bureau. 2006. 2006 National survey of fishing, hunting, and wildlifeassociated recreation. $162 \mathrm{pp}$.

Van Voorhees, D., and E. S. Pritchard. 2008. Fisheries of the United States. July 2008. National Marine Fisheries Service, Office of Science and Technology 2007 Preliminary Report on Commercial and Recreational Fisheries of the United States. 103 pp.

Waples, D. M. 1995. Activity budgets of free-ranging bottlenose dolphins (Tursiops truncatus) in Sarasota Bay, Florida. M.S. thesis. University of California, Santa Cruz, CA. 61 pp.

Wells, R. S. 1991. The role of long-term study in social structure of a bottlenose dolphin community. Pages 199-225 in K. Pryor and K. S. Norris, eds. Dolphin societies: Discoveries and puzzles. University of California Press, Berkeley, CA.

Wells, R. S. 2003. Dolphin social complexity: Lessons from long-term study and life history. Pages 32-56 in F. B. M. de Waal and P. L. Tyack, eds. Animal social complexity: Intelligence, culture, and individualized societies. Harvard University Press, Cambridge, MA.

Wells, R. S., and M. D. Scott. 1994. Incidence of gear entanglement for resident inshore bottlenose dolphins near Sarasota, Florida. Report International Whale Commission (Special Issue 15):629.

Wells, R. S., A. B. Irvine and M. D. Scott. 1980. The social ecology of inshore odontocetes. Pages 263-317 in L. M Herman, ed. Cetacean behavior: Mechanisms and functions. Wiley \& Sons, New York, NY.

Wells, R. S., M. D. Scott and A. B. Irvine. 1987. The social structure of free-ranging bottlenose dolphins. Pages 247-305 in H. Genoways, ed. Current mammalogy. Volume 1. Plenum Press, New York, NY.

Wells, R. S., S. Hofmann and T. L. Moors. 1998. Entanglement and mortality of bottlenose dolphins, Tursiops truncatus, in recreational fishing gear in Florida. Fishery Bulletin 96:647-650.

Wells, R. S., J. B. Allen, S. Hofmann, K. Bassos-Hull, D. A. Fauquier, N. B. Barros, R. E. Delynn, G. Sutton, V. Socha and M. D. Scott. 2008. Consequences of injuries on survival and reproduction of common bottlenose dolphins (Tursiops truncatus) along the west coast of Florida. Marine Mammal Science 24:774-794.

Whitehead, H. L., L. Rendell, R. W. Osborne and B. Würsig. 2004. Culture and conservation of non-humans with reference to whales and dolphins: Review and new directions. Biological Conservation 120:427-437.

Williams, R., D. Lusseau, and P. S. Hammond. 2006. Estimating relative energetic costs of human disturbance to killer whales (Orcinus orca). Biological Conservation 133:301-311.

Würsig, B., and M. Würsig. 1977. The photographic determination of group size, composition, and stability of coastal porpoises (Tursiops truncatus). Science 198:755-756.

Zollett, E. A., and A. J. Read. 2006. Depredation of catch by bottlenose dolphins (T. truncatus) in Florida king mackerel (Scomberomorus cavalla) troll fishery. Fishery Bulletin 104:343349.

Received: 25 August 2009

Accepted: 4 March 2010 